\title{
TIMSKO DELO V SLOVENSKI VOJSKI
}

\section{TEAM WORK IN THE SLOVENIAN ARMED FORCES}

Povzetek Na izbor članka je vplivalo dejstvo, da v organizaciji, kot je Slovenska vojska, premalo pozornosti namenjamo timskemu delu, čeprav je opredeljeno v normativnih aktih Slovenske vojske. Glavni cilj članka je prikazati pogoje za nastanek tima, kdaj se odločamo za timsko delo ter kateri elementi timskega dela so uporabni ali so lahko podlaga timskemu delu v Slovenski vojski (SV). Pri tem bom upošteval teoretična načela za oblikovanje timov in iz preučenih gradiv prikazal, kako in kdaj izbrati primerno strukturo skupine/tima, z opredelitvijo vloge posameznika v njej, vodje tima in pogojev, v katerih oblikujemo učinkovit tim. Paziti moramo na primer na klimo v timu in motivacijo za delo v timu, saj bomo le tako dosegli primerne rezultate. Namen članka je opozoriti na organizacijo, organiziranje in organiziranost, predvsem pa na dejavnike, ki vplivajo na dogajanje v timu, in na to, kako preprečiti negativne pojave v njem. Prikazal bom, kako se lahko rešujejo težave v procesu dela. Opozoril bom na teoretična načela pri oblikovanju timov ter opredelil, kateri elementi timskega dela so uporabljeni in so podlaga za izvajanje procesov v organizacijskih enotah Slovenske vojske. V sklepnem delu članka bom na podlagi izkušenj predstavil dejavnosti uveljavljanja timskega dela v Slovenski vojski s praktičnim primerom. Cilj pa je tudi prikazati pomembno vlogo vodilnega osebja oziroma vodij, ki sestavljajo in vodijo time.

Ključne Organizacija, organiziranje, organiziranost, usposabljanje, izobraževanje, besede skupina, tim, timsko delo, vojaška organizacija, ustvarjalnost, učinkovitost.

Abstract This article has been motivated by the fact that team work is not paid due attention, although it is stipulated by the legal norms of the Slovenian Armed Forces (SAF). The main purpose of this article is to show which requirements need to be met in order to build a team, which situations are appropriate for team work, and which elements of team work can be applied to observe as a basis of team work in the SAF. 
This article relies on theoretical principles that pertain to the formation of teams. Based on a study of relevant materials it recommends how and when we can determine an appropriate structure of a group/team, identify the role of an individual in a team, the team leader, and which conditions need to be fulfilled for a team to be successful. Good results can only be achieved in a good atmosphere and in a stimulating environment. This article describes the structure and organization principles of a team, in particular factors that influence team dynamics, and to show how negative developments can be prevented. It depicts how problems are being solved in the work process. In the conclusion, activities for the promotion of team work in the SAF are presented, based on a practical example. In addition, important roles of the management who compose teams and team leaders are summarized.

Key words Structure and organization principles, education and training, group, team, team work, military organization, creativity and efficiency.

\section{OPREDELITEV ORGANIZACIJE, ORGANIZIRANJA IN ORGANIZIRANOSTI}

Organizacija pomeni neko strukturo, organizacijski sistem. Poudarek je na nizu elementov, ki so na določen način sestavljeni in medsebojno povezani v določene odnose. Torej lahko rečemo, da organizacija združuje ljudi, ki so povezani med seboj, da bi dosegli določen cilj - zaželeno stanje. Organiziranje je proces, ki ga lahko razumemo kot urejanje oziroma proces urejanja organiziranosti. V zvezi z organiziranostjo se ponuja zahteva po usklajevanju in usklajenosti. To je posebno pomembno pri usklajevanju strukturnih sestavin med seboj in glede na cilje kot želene izide. Potrebne so še drugačne razsežnosti usklajevanja, npr. časovno usklajevanje, ki je sočasno stvar načrtovanja. Koordinacija je v tem primeru usklajevanje v okvirih sistema po nadsistemih in podsistemih. To je popolnoma skladno s teorijo sistemov. Organiziranost (sedanja, pretekla ali prihodnja) pa se pokaže kot urejenost oziroma stanje urejenosti organizacijskega sistema. Besedi urejenost in urejanje se kar ponujata za pojmovanje stanja in procesa organizacije.

\section{TIMSKO DELO}

\section{Uvodna pojasnila}

Le redko ljudje opravljajo svoje delo sami. Po navadi so združeni v manjše ali večje skupine. Kako dobro in koliko dela opravlja posameznik v skupini, je odvisno od njihovega znanja, usposobljenosti, notranje motiviranosti, kreativnosti, prizadevanja za skupno doseganje cilja, odnosa do dela, uporabe tehničnih sredstev in tehnologije. Vsekakor je vloga vodje v skupini zelo pomembna, odločilna, ker stalno vzdržuje tim kot sistem, v katerem prideta do izraza soodvisnost in povezljivost. 
Timsko delo je postalo oblika dela zato, da so se laže reševali problemi oziroma naloge. Učinkovitost tima ni odvisna samo od znanja in sposobnosti članov, temveč tudi od načinov in posebnosti posameznikovega vključevanja $v$ delo tima. $\mathrm{Ob}$ tem se člani tima srečujejo z osebnimi nalogami, pri katerih prideta do izraza tako konstruktivnost njihovih miselnih prispevkov kakor čustveno vključevanje $\mathrm{v}$ skupino. To pomeni, da smo na individualni ravni v glavnem priča usklajevanju miselnih razlik in pogledov na eni strani in uravnavanju medsebojnega doživljanja na drugi strani.

Dober tim je socialni sistem, ki daje posamezniku možnost, da izrazi svoje delovne in človeške vrednote. $\mathrm{V}$ dobrem timu prihaja do sinteze vrednot in njihove nove kakovosti. Zato ni najučinkovitejša tista skupina oziroma tisti tim, ki je sestavljen iz najučinkovitejših posameznikov, ampak tisti, ki v interakciji vseh svojih posameznikov daje najboljše rezultate. Torej ni dovolj, da so posamezniki kakovostni, kakovostna mora biti skupina, kateri pripadajo. Tudi strokovnjaki pri preučevanju organizacije dela v podjetjih in drugih ustanovah ugotavljajo, da za organizacije niso tako zelo pomembni odlični posamezniki, ampak in predvsem odlični delovni timi.

Lahko pa se pojavi težava, ker se veliko vodij prehitro zadovolji s sestavo tima. Zaradi njihove lahkomiselnosti se lahko zgodi, da tim ne daje pričakovanih rezultatov, predvsem zato, ker ne upoštevajo, da pri delu nastajajo težave. Lahko pride do nesoglasij in konfliktov med ljudmi, ki so mnogokrat vsakodneven pojav v večjih ali manjših sistemih ali med posamezniki. Posamezniki, združeni v skupino, ki so prej povsem složno opravljali neko drugo delo, se v novi skupini nekako ne znajdejo. Kdor pričakuje, da bo skupina oblikovana zaradi izvedbe določene naloge, začela takoj dobro sodelovati in dosegati dobre rezultate dela, je v veliki zmoti. Da bi se vsemu temu izognili in dosegli dobre rezultate, bi morali biti tako posamezniki kot delovne zahteve v medsebojni interakciji. Ustvariti bi morali primerno delovno okolje tako za posameznika kakor za organizacijo oziroma skupino.

Dva državna organa sta lahko podobna ali enaka po funkciji in pristojnostih, po številu zaposlenih, imata podobno ali enako informacijsko tehnologijo, vendar je eden uspešnejši od drugega. Marsikaj vpliva na storilnost, učinkovitost, uspešnost, toda vse bolj prevladuje spoznanje, da so ljudje ključen dejavnik. Zato je na mestu vprašanje, kako naj ravnamo z ljudmi, da bomo dosegli cilje organizacije in hkrati zagotovili zadovoljstvo zaposlenih. Vojaška organizacija se bistveno ne razlikuje $\mathrm{v}$ primerjavi z drugimi organizacijami. Ena od posebnosti pa je, da sta vodenje in ravnanje zaposlenih in poklicnih vojakov bolj celovito in natančno urejeni $s$ predpisi. Hierarhija zaposlenih, ki je sicer značilna za vse poklice, ni nikjer tako odločilna pri opravljanju delovnih dolžnosti kakor v sistemu, kot je vojska; v njej namreč velja razmerje nadrejenosti in podrejenosti, načelo enostarešinstva, načelo vojaške subordinacije itn. Z gledišča strokovne strukturiranosti pripadnikov vojaške organizacije pomeni razmerje nadrejenosti in podrejenosti sredstvo za zagotovitev funkcioniranja in strokovnosti delovanja vojaške organizacije. 
Veliko poveljujočega kadra je zavedeno zaradi takšnih razmerij v vojski in načina dela na vseh ravneh vodenja in kontrole. Znano je, da mnogi iščejo pravo bistvo svojega delovanja v smeri, ki vodi v specializacijo področja, ki ga dobro obvladujejo. S tem pa velikokrat poskrbijo samo za svojo prezaposlenost in zaradi dreves ne vidijo gozda. To je tudi razlog, da poveljniki navadno pozabljajo na svoje podrejene, ki so največkrat premalo zaposleni, premalo obremenjeni in nezadostno izkoriščeni glede na njihovo znanje in sposobnosti.

\section{POGOJI ZA NASTANEK TIMA}

Do sredine 20. stoletja je bilo stanje v zunanjem okolju - na trgu (v družbi nasploh) razmeroma stabilno in je omogočalo postavljanje lahko dosegljivih ciljev. Vodilni ljudje v podjetjih so si zamišljali organizacijo kot piramido. Vsak del piramide je moral doseči svoj cilj in zaradi tega se je zgradil sistem, ki je takšni organizaciji omogočil, da je uresničila vse cilje. Ljudje so bili administrativno vključeni v sistem. Bili so njegov sestavni del in vse je bilo mogoče zelo natančno in predvidljivo načrtovati. V tistem času so bile spremembe v okolju majhne in je bilo mogoče iz trendov preteklosti zelo natančno načrtovati prihodnost.

Takšno stanje ekonomičnosti je omogočalo razraščanje birokracije in gradnjo imperija. Delovni proces je bil za izpolnjevanje nalog razbit na veliko delov z razdrobljenimi procesi, ki so jih opravljali ljudje v funkcionalnih oddelkih. Rezultat je bil birokratska ohromljenost, pomanjkanje inovacij in visoki režijski stroški.

Takšna organiziranost je bila in je še marsikje v državni upravi in vojski, ki se najtežje spreminjata oziroma preoblikujeta. Organizacija državne uprave in vojske ni tako izpostavljena vplivom zunanjega okolja oziroma pritiskom trga in s tem prisiljena, da racionalno preoblikuje organizacijo in delovne procese. Konkurenca na trgu je postajala vedno večja, oblikovalci organizacij so potrebovali več novih idej in domiselnosti pri postavljanju ciljev in njihovi realizaciji. Hitrejši napredek so dosegli z vključevanjem ljudi v time, s tem so sprostili njihove ideje pri skupnem delu.

Tako kot se to uveljavlja $\mathrm{v}$ podjetjih in drugih organizacijah, ki so izpostavljene trgu zaradi novih zahtev, ne moreta ostati imuni na nove oblike organiziranosti niti naša državna uprava niti Slovenska vojska kot njen specifični del. Zaradi nenehnih zahtev okolja po zniževanju javne porabe, večji učinkovitosti in demokratizaciji sta prisiljeni, da spreminjata svoje upravljavske sheme.

To narekuje povečanje učinkovitosti veljavnih sistemov zaradi oblikovanja novih institucij, ki morajo podpirati spremembe $\mathrm{v}$ pravnem in političnem sistemu. Vsi sistemi v SV morajo postali timsko naravnani in notranje učinkoviti, saj se bo Slovenija s takšno organiziranostjo laže vključila v evroatlantske oziroma mednarodne integracije. 
Bolj kot do sedaj se bodo pokazale precejšnje razlike v napovedovanju in presojanju nekega problema, saj ljudje v enakih položajih ne reagirajo enako. Vsak posameznik v skupini ima svoje cilje in poglede pri reševanju kompleksnih situacij, nekateri so manj sposobni, drugi bolj nadarjeni. Da bi te razlike med posamezniki ublažili, lahko le z motivacijo o pripadnosti skupini pripeljemo skupino do uspešnega dela in do uresničevanja skupnih ciljev. Motiviranje zaposlenih mora biti temeljni cilj in celo želja vodilnega osebja. Če so ljudje zadovoljni, opravljajo delo po svojih najboljših močeh; največja odgovornost vodij skupin je ustvarjati notranjo harmonijo, zaradi oblikovanja visoko učinkovite in samostojne skupine.

Vodilno osebje v javni upravi ima razne naloge in pooblastila, odvisno od položaja v hierarhični strukturi. Med vodilno osebje štejemo vse tiste, ki vodijo: od vodje najmanjše organizacijske enote do ministra ali direktorja urada, agencije, zavoda itn.

Naloga vodij je, da s svojim znanjem iz posameznikov in njihove nadarjenosti izvlečejo najboljše oziroma da njihove pomanjkljivosti nadomestijo s prednostmi drugih. Zato ni dovolj, da imajo znanje samo iz vodenja, njihovo znanje mora biti obsežno, ker morajo poznati problematiko s posameznih področij, ki so združena v timu. Torej mora vodja tima komunicirati s strokovnjaki s posameznih področij in vzpostaviti takšno klimo, da zaposleni odprto, spontano in z občutkom za realnost prikažejo svoje vizije širšemu krogu zaposlenih, predvsem pa timu, ki mu pripadajo. Da bi bili vodje učinkoviti pri svojem delu, naj uporabljajo zelo preprosto metodo interakcije s sodelavci, ki se imenuje vodenje po zlatem pravilu: Ravnaj z drugimi tako, kot si želiš, da bi oni ravnali s teboj. To pravilo temelji na vljudnosti, ljubeznivosti in spoštovanju v odnosu do vseh ljudi, zlasti do ljudi, ki so podrejeni.

Vloga vodje v skupini je zelo pomembna in izpostavljena. Če vloga vodje ni že vnaprej določena, jo moramo oblikovati med prvimi. Z vlogo vodje je močno povezan proces socialnega vplivanja. Oblikovanje in vzdrževanje delovnega okolja, ki vzbuja veliko medsebojnega zaupanja, je ena najpomembnejših stvari, ki jih vodja lahko stori v skupini. Ključ do ustvarjanja prijetnega delovnega okolja, v katerem je visoka stopnja zaupanja, je odprava strahu iz delovnega okolja. V delovnih okoljih se pojavljajo nesporazumi ali prihaja celo do manjših ali večjih prepirov, toda nikogarne bi smelo biti zaradi tega strah. Ljudje izražajo svoja mnenja, povedo, kar mislijo, kaj želijo storiti, kaj si zamišljajo, kaj hočejo in drugo. Takšni sprejemajo le določeno vrsto nadrejenih, tistih, ki ustvarjajo ugodno psihosocialno klimo. Ni jih strah tudi, če naredijo napake, ki se pojavijo kljub skrbnemu premisleku in dobremu namenu. Uveljavljanje oziroma uvajanje timskega dela v Slovensko vojsko je nekoliko težja naloga, saj je to sistem z obvezno subordinacijo, disciplino in enostarešinstvom. Prepričan sem, da bi to nalogo laže izvedli z raznovrstnim izobraževanjem in usposabljanjem vseh zaposlenih, predvsem pa vodstvenega kadra, saj zaposleni danes potrebujejo vedno več novega znanja in veščin. Dosegli bi višjo stopnjo izobraženosti in usposobljenosti ter s tem bistveno hitrejši pretok potrebnih informacij. To bi seveda pripomoglo $\mathrm{k}$ zmanjšanju nepotrebnega odpora do kakovostnih sprememb. Eden od pristopov za spoprijemanje s spremembami 
iz okolja je koncept učeče se organizacije, ki temelji na izboljševanju sposobnosti organizacije, ki zahteva nenehen osebni razvoj in neprestano učenje posameznika. Le tako bi si omogočili preoblikovanje organizacije dela v vojaški strukturi in dialog z vsemi ustvarjalnimi $\mathrm{v}$ njej, in to na vseh ravneh odgovornosti. Z novim teoretičnim znanjem, s sprostitvijo ustvarjalne domišljije vseh zaposlenih in $\mathrm{Z}$ drugačnim pristopom do organizacije dela v naši vojski bi lahko dosegli boljšo organiziranost vojaške organizacije, delovnih sistemov in seveda delovne procese v njih. Kljub temu se morajo ohranjati pravila vojaške hierarhije in načelo vojaške subordinacije. Iz navedenega izhaja, da bi morali funkcijsko organiziranost vse bolj nadomeščati s procesno.

Slika 1:

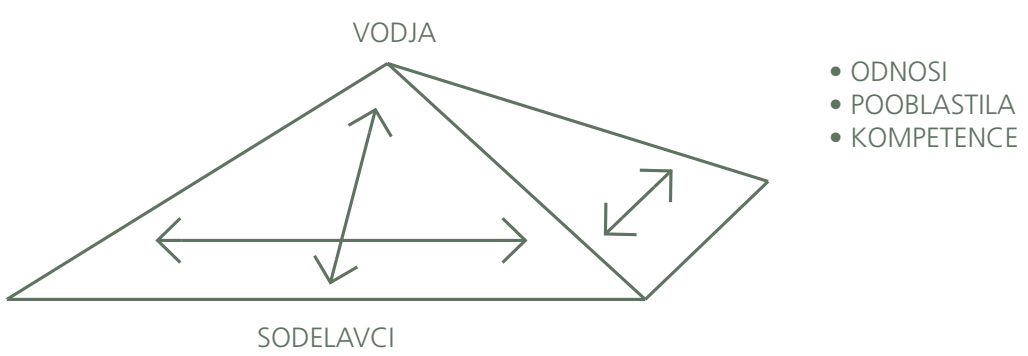

»ŽIVLJENJE NAJ BO STROKOVNO POLNO IN ČLOVEŠKO ZNOSNO! «

Učinek skupine ni odvisen samo od posameznikov, ampak predvsem od sinergijskega učinka, ki je povezan z emergenco (na novo nastajajoče stvarnosti), pri katerem iz skupine posameznikov nastane tim. Vse bolj postaja jasno, da se kakovostno delo lahko doseže večinoma z organiziranjem delavcev, da delajo skupaj. Posameznik lahko veliko spremeni v neki organizaciji, vendar pa imajo le redki dovolj znanja in izkušenj, da bi razumeli vse procese, ki nastajajo znotraj organizacije. Ob nekem dolgotrajnem projektu bi posamezniku motivacija verjetno sčasoma upadla. Timsko delo pa prepreči take in podobne težnje v organizaciji in zagotovi posameznikovo angažiranost za dokončanje naloge.

\section{ODLOČANJE ZA TIMSKO DELO}

V vsaki organizaciji, tako tudi v vojaški, se vsakodnevno srečujemo s težavami in z nalogami, ki jih je treba rešiti oziroma izvesti. Od obsega naloge je odvisno, ali bomo to dodelili posamezniku ali skupini. Težje naloge bomo prav gotovo zaupali določeni skupini ljudi, ker so za posameznika mnogokrat preobsežna in strokovno zahtevna. Nazadnje je treba ugotoviti, koliko članov naj šteje skupina in kako naj bo sestavljena glede na znanje ter osebnostne lastnosti. Skupinsko delo je sicer zelo pogosta in priljubljena oblika dela, vendar se tudi tukaj pojavljajo zelo različna stališča. Nekateri so kritični, češ da ima skupinsko delo naslednje pomanjkljivosti: 
neustrezno opredeljeno delo, izguba časa za usklajevanje, nejasno opredeljene dejavnosti posameznika, zbeganost, začetno oklevanje, zahajanje v podrobnosti, slabo razdeljene vloge, nespoštovanje organizacije dela, heterogenost skupine, zaverovanost posameznikov v lastne rešitve in različna raven predznanja. Med temi nasprotji pa so tudi prednosti. Tako sta na primer homogenost in heterogenost skupine, kot smo že v uvodu opozorili, neposredna vzroka za učinkovitost ali pa neučinkovitost skupine. Mnogi pa vidijo prednosti dela v skupinah, ker so opazili naslednje: hitro končano delo, sprotno sporazumevanje, skupno opredeljevanje stališč ipd. Prednosti naj bi izhajale iz homogenosti skupine, skladnosti sodelujočih, možne uskladitve mnenj, odprtosti članov skupine, različnih pogledov na problem, upoštevanja vseh mnenj in hitre izmenjave teh, spoštovanja predlogov, učinkovitega sodelovanja itn.

To, kar ljudje potrebujejo, je pripadnost, občutek, da so del nečesa, kar jim daje identiteto in varnost. Potrebujejo tudi občutek pripadnosti ustvarjalni skupini, ki poskuša doseči zanje nekaj dragocenega, vrednega truda. Če pogledamo v zgodovino, so bili ljudje resnično srečni, ko so bili popolnoma predani doseganju nečesa, za kar se je bilo vredno truditi. Če se hoče ustvariti samostojna skupina, se morajo predvsem upoštevati ljudje in zadovoljiti dve njihovi globoki notranji potrebi: po avtonomnosti in po pripadnosti skupini.

Ko sestavljamo tim, nam pomaga, če so glede na značilnosti članov zastopani vsi vidiki reševanja problemov. Če v timu prevladujejo »izvirni misleci« in »zaključevalci« implementatorji, manjkajo pa ljudje, ki bi spretno izbirali in ovrednotili ideje ter od tod izpeljali načrt, se takemu timu lahko pogosto dogaja, da zna navdušiti okolico za svoje ideje, a se velikokrat prenagli zaradi neizdelanosti zamisli. Tak tim počasi izgublja podporo med sodelavci, saj so načrti slabo izbrani in premalo konkretni, da bi bili uspešni. Pomembno je, da znamo prepoznati bistvene nagibe posameznikov in da vemo, da se je s treningom mogoče tudi priučiti veščin, ki so potrebne v fazah, ki morda nam niso najbližje.

Iz opisanega lahko ugotovimo, da ni povsem enotnega stališča, kakšna naj bo sestava skupine, dvomimo o pričakovanih rezultatih, zaskrbljeni smo zaradi hitrosti del itn. Naša želja pa je, da imamo skupino ljudi - TIM, ki lahko uspešno reši nalogo. Uspešno pomeni, da je naloga opravljena pravočasno in da so gospodarno izrabljeni tako notranji kot zunanji viri. Vsak član prispeva po svojih zmožnostih.

Spodnji diagram nazorno prikazuje strukturo dela $\mathrm{v}$ timu in notranjo procesnost, ki ustvarja želene rezultate. Potek dejavnosti pri organiziranju timskega dela je prikazan v naslednjem diagramu na sliki 2.

Pomembnost skupinskega oziroma timskega dela v vsaki organizaciji je očitna, saj večino časa preživimo v medsebojni interakciji v uradnih in neuradnih pogovorih, sestankih, krožkih, posvetih, projektnih in delovnih timih in podobno. Še posebej to velja za vodje na vseh ravneh, ki morajo redno komunicirati s sodelavci ter reševati probleme, ki se nanašajo na medosebne, delovne in poslovne zadeve. 


\section{OPREDELITEV SKUPINE}

Vsakdo izmed nas pripada neki skupini: delovni, športni, socialni, prijateljski, politični. Skupine se razlikujejo po nekaterih značilnostih, vendar ima vsaka tudi nekaj osnovnih potez, zaradi katerih jo lahko imenujemo skupina. Vsaka ima določeno število članov, to število pa bistveno spreminja odnose in procese, ki se razvijajo v skupini. Glede na število članov ločimo:

- diade, skupine z dvema članoma,

- triade, skupine s tremi člani, in

- druge oblike, skupine z več člani.

Slika 2:

Potek dejavnosti pri organiziranju timskega dela

Vir: Pavlič,

Tomaž,

Oblikovanje tima

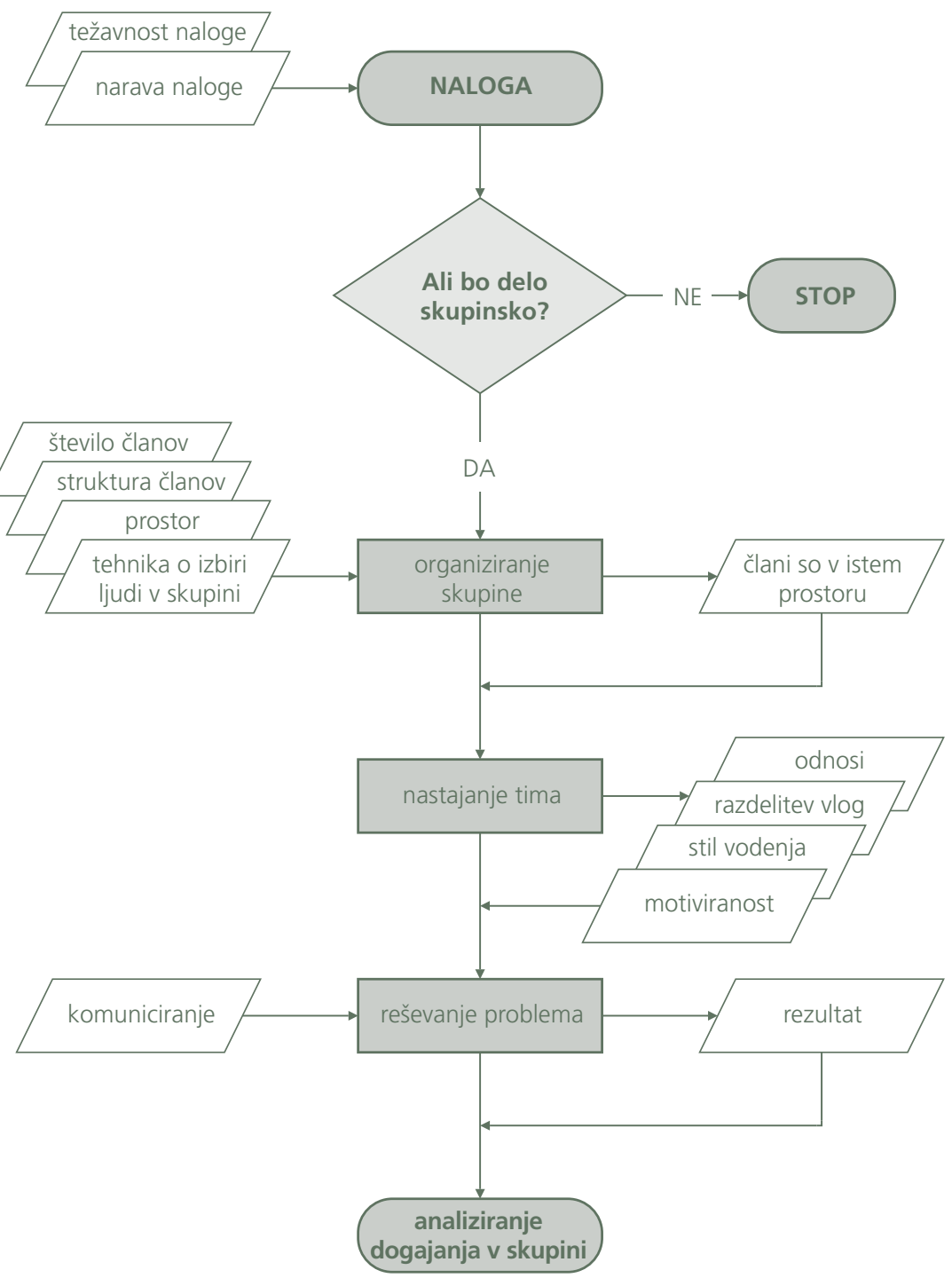


Posameznik se povsem drugače vede in komunicira v diadi kakor v triadi. V diadi so odnosi veliko bolj intenzivni in navezanost je obojestranska. V triadi se to že poruši, le v redkih primerih se to izraža $v$ vsestranskih odnosih. $Z$ večanjem števila članov tudi skupinske značilnosti bledijo. Pri številu več kot 15 članov v skupini lahko najdemo le eno ali nekaj skupnih potez. Predvsem se v velikih skupinah ljudje med seboj ne poznajo tako dobro niti nimajo realne možnosti, da bi vsakdo v skupini imel stike z vsemi.

Osnovna nujnost vsake skupine je sposoben vodja, okoli katerega se drugi člani združujejo, se z njim poistovetijo, omogoča jim uresničevanje teženj, ki jih sprožijo osebne potrebe. Najpomembnejši za skupino je vsekakor skupni cilj. Člani skupine s ciljem dosežejo svoj namen. Če so cilji in potrebe članov različni, je bolje cilje prilagoditi članom kakor poskušati spreminjati njihove potrebe. Ključ do visoko učinkovite skupine je zelo preprost - ključ je v harmoniji, ki so jo dosegli vsi člani skupine. Da nekemu številu ljudi lahko rečemo skupina, mora imeti naslednje značilnosti:

- skupina mora biti spoznavna in določljiva po članih, ki jo sestavljajo,

- imeti mora socialno strukturo, ki določa položaj člana in odnose med njimi,

- obstajati morajo recipročni odnosi, ki zagotavljajo stike in komunikacijo med člani,

- v skupini mora obstajati vloga posameznika, prek katere član sodeluje v skupini, brez njegovega dela skupina preneha obstajati,

- vsaka skupina ima svoje norme, po katerih član oblikuje svoje vedenje,

- člani skupine imajo določene skupne interese, ni nujno, da so natančno določeni,

- delovanje skupine mora biti usmerjeno k skupnemu cilju,

- skupina mora imeti določeno trajnost.

Skupine načeloma delimo na dve vrsti: formalne in neformalne. Formalne skupine imajo natanko določene naloge in cilje. Vsak posameznik ima $\mathrm{v}$ taki skupini določeno mesto oziroma položaj in naloge. Takšna skupina nastane z uradnim, formalnim aktom. Vnaprej ima določene vodjo, cilje, delovne naloge in pogoje za obstoj. Formalne skupine so glede na mesto, obseg in vsebino dela opredeljene v organizacijsko shemo (izrazit primer formalne skupine je vojska).

Neformalne skupine nastanejo z medsebojnim povezovanjem med ljudmi. Ukvarjajo se z zadevami, ki niso uradno delovne, ampak se nanašajo na zadovoljevanje interesov, potrebo po pomoči, po razvijanju prijateljstva in podobno. Neformalne skupine lahko podpirajo ali ovirajo cilje v skupini ali pa so do njih nevtralne. Organizacijska struktura in način vodenja močno vplivata na nastanek in vsebino delovanja neformalnih skupin. Nazoren primer nastanka takih skupin je uvedba dvoizmenskega dela, ki onemogoča neposreden stik med člani. Taka delitev lahko pripelje do negodovanja, če vodja postavlja v ospredje doseganje delovnih rezultatov, pa se lahko zgodi, da se neformalne skupine usmerijo proti nadrejenemu. 
V prihodnosti bo značilna uporaba skupinskega znanja v organizaciji. To skupinsko znanje se bo uporabljalo po formuli:

$$
\begin{gathered}
\text { znanje }=(\text { osebe }+ \text { informacije }) \times \text { skupinska uporaba }=\text { napredek } \\
\text { oziroma } \\
Z=(O+I) \times S U=N
\end{gathered}
$$

Ta formula lepo ilustrira nedeljivo povezanost znanja, informacij in skupinske uporabe, ki nedvomno vodi k napredku.

\section{OPREDELITEV TIMA}

Zgoraj navedene značilnosti skupin lahko ustvarijo napačno prepričanje, da je preprosto oblikovati skupino, ki naj bi delovala uspešno. Vendar v praksi to povsem ne drži, kljub znani teoriji in praksi. Kadar je v neki organizaciji veliko skupin, v katerih ni pravega sodelovanja, začne uspešnost take organizacije počasi »šepati«. Če skupine že same po sebi ne delujejo uspešno, se bodo še težje povezovale z drugimi skupinami, s katerimi opravljajo določena dela. V primerjavi s formalno delovno skupino lahko pomeni tim povsem novo kakovost in možnost. Ustvarjalni tim deluje kot umsko omrežje, ki presega formalno organizacijo posameznikov, skupin, delovnih enot ..., saj omogoča in pospešuje sproščanje ustvarjalnih potencialov nad osebno zmožnostjo posameznika.

Temeljne značilnosti ustvarjalnega tima so nadseštevnost

$$
(1+1>2) \text {, }
$$

vzajemni učinki, velika prožnost, napovedana moč in hitrost učenja, predvsem pa večja verjetnost in hitrost ustvarjalnih dosežkov. Tim se razvija v smeri nastajanja svojstvenega spodbudnega ozračja, kolegialnega prijateljstva, ustvarjalnega zanosa in notranje kulture, ki temelji na značilnih skupinskih vrednotah, vedenja, občutka za lepo, čuta za pravično in podobno.

Graditev tima lahko ponazorimo s sestavljanjem lego kock in izraz tim nam danes predstavlja ravno to: gradbene »kamne« v organizaciji. Le pravilna izbira in postavitev vsakega »kamna« nas pripeljeta do uspešnih timov in s tem

organizacije. Tim je skupina, v kateri imajo posamezniki skupen cilj le zato, ker se njihova strokovna usposobljenost, veščine in druge lastnosti ujemajo, skladajo z drugimi člani skupine. Kadar oblikujemo uspešne time, govorimo o dveh pomembnih sestavinah:

- izbiri članov tima in

- usposabljanju tima. 
Slika 3: Matrika usposabljanja in razvoja organizacije

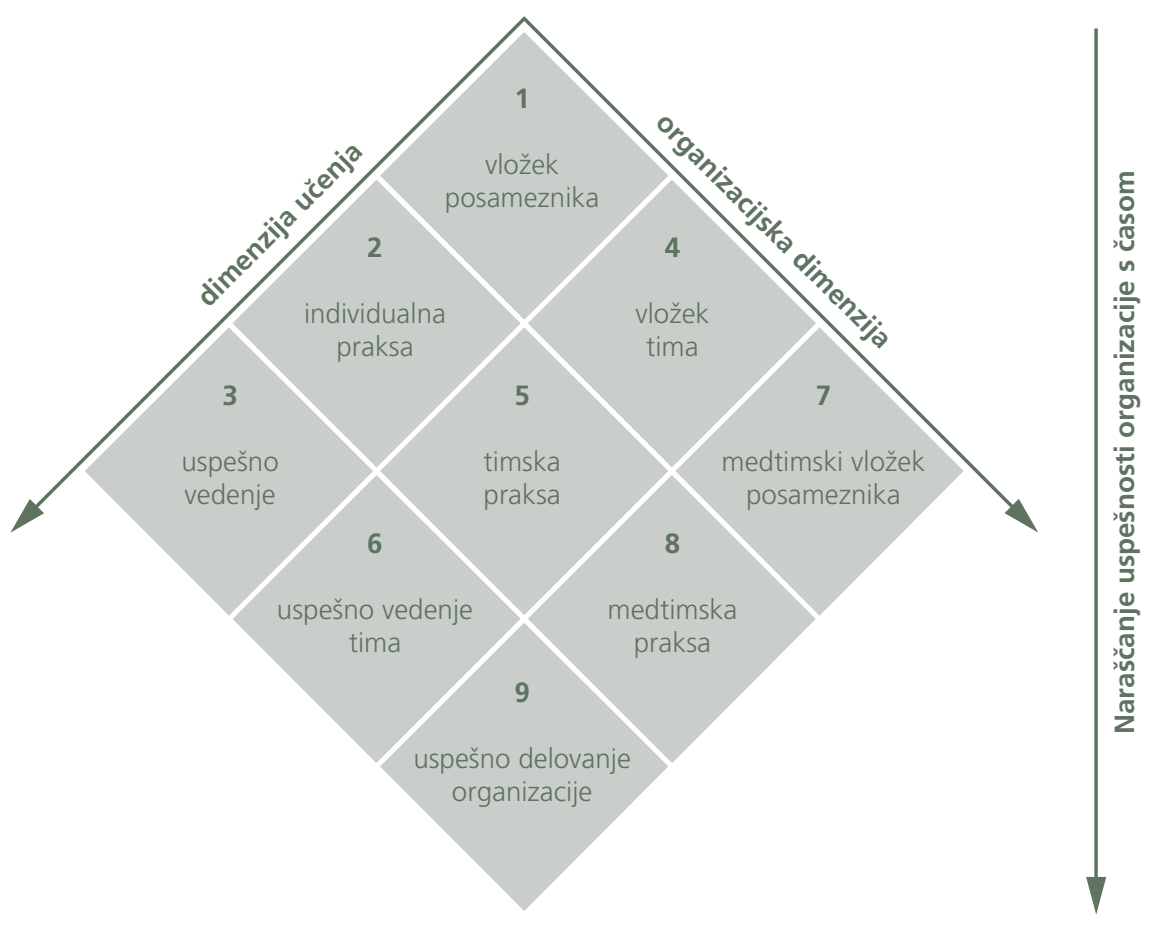

Usposabljanje tima se lahko začne na dva načina. Lahko začnemo z inštrukcijami o osnovah, ki opredeljujejo sestavljanje uspešnih timov. Lahko pa uporabimo drugo metodo, ki takoj začne z dano nalogo in člani sami prepoznavajo delovanje uspešnega tima. Zatem se usposabljajo in stalno ocenjujejo lasten razvoj ter končno obvladajo vse potrebne spretnosti. Tudi povezovanje med timi lahko urimo in pregledujemo ter tako zagotovimo uspešen razvoj celotne organizacije.

Slika 3 prikazuje povezanost med člani, timi in organizacijo. S tem sem hotel nazorno dokazati prepletenost, povezljivost in soodvisnost v procesu, ki se sproža v vsakem timu. Ta je oblikovan iz vrste strukturnih elementov, ki so na sliki nazorno prikazani.

Posamezniki in timi vlagajo znanje in sposobnosti za to, da bi čim bolje opravljali delo, rezultati pa kažejo, kako uspešni so bili. Sodelovanje med člani omogoča pridobivanje izkušenj in nenehno izobraževanje.

Razvoj tima se začne tedaj, ko se ljudje odločijo, da bodo sodelovali pri določeni nalogi. Oblikovanje tega lahko poteka različno. Uspešno oblikovanje naj bi potekalo po naslednji nekoliko skrčeni shemi, ki vsebuje naslednja vprašanja:

- Kaj so cilji organizacije?

- Kaj so cilji tima, skupine?

- Kaj so cilji posameznega člana?

- Kaj bi radi dosegli v posameznih časovnih obdobjih? 
- Kako bi radi to dosegli?

- Kaj pričakujemo od posameznih članov?

- Kaj pričakuje vodstvo od tima?

- Kdo odloča?

- Kako naj bodo odločitve opredeljene?

- Ali je tim ustrezno organiziran?

- Kakšna je morala, kultura dela v timu?

- Ali se da izboljšati?

- Kako uspešno timi sodelujejo?

- Kako navzgor in kako navzdol?

- Kaj in v čem je naša prednost?

- Ali lahko popravimo slabosti?

- Kateri so problemi?

- Ali imamo težave, ki bi jih morali upoštevati?

Po tej shemi naj bi bili člani sposobni odkrivati aktualne probleme. Predvsem je pomembno, da znamo ločiti razlike, ki nastanejo v primerjavi skupine in tima. V spodnji tabeli so glavne razlike med njima, čeprav sta lahko oba sestavni del v isti organizaciji.

Timski način dela je praktično nepogrešljiv takrat, ko pot reševanja, rešitev, število rešitev in način reševanja problema niso znani. $V$ takih primerih si želimo več mnenj, ki po usklajevanju dajo najboljšo rešitev. Poskus sestaviti skupino s podobnim, vendar pa heterogenim znanjem in s takšnimi osebnostnimi lastnostmi, ki omogočajo hitrejše nastajanje tima, mora biti namen in želja vsakega vodje.

Prednosti timskega dela se kažejo v več pogledih:

- znanje in informacije, ki jih ima tim, so praviloma večji od znanja kateregakoli člana,

- člani v timu lahko z razpravo in izmenjavo mnenj pridejo do raznih odločitev, $\mathrm{v}$ primerjavi z rešitvami, dobljenimi po ustaljenih poteh,

- člani, ki lahko vplivajo na odločitev, so tudi bolj sprejemljivi za skupne rešitve,

- zaradi sodelovanja pri reševanju problema člani bolje razumejo končne odločitve.

Prav tako ne smemo pozabiti na pomanjkljivosti timskega dela. Tako se lahko pojavi skupinsko razmišljanje, ki ne daje najboljših rešitev, prevlada posameznika v razpravi ali pa se v vnemi pri pomoči spregledajo cilji. Poraba časa je pogosta predvsem pri večjih skupinah in to je ena izmed napak timskega dela, ki pa seveda ni usodna. 
Tabela 1:

Razlike med timi in skupinami

\begin{tabular}{|c|c|}
\hline Skupine & Timi \\
\hline $\begin{array}{l}\text { Člani menijo, da so organizirani v skupine iz } \\
\text { administrativnih razlogov. Posamezniki delajo } \\
\text { neodvisno, le včasih, če so cilji skupni, pa v } \\
\text { povezavi z drugimi. }\end{array}$ & $\begin{array}{l}\text { Člani spoznavajo svojo medsebojno odvisnost } \\
\text { in vedo, da se osebni in timski cilji dosegajo } \\
\text { najuspešneje z vzajemno pomočjo. Ne izgubljajo } \\
\text { časa s prepiri okrog tega, kam spada določeno } \\
\text { delo, niti se ne poskušajo osebno okoristiti na } \\
\text { račun drugega. }\end{array}$ \\
\hline $\begin{array}{l}\text { Ker člani niso dovolj vključeni v načrtovanje ciljev } \\
\text { skupine, skušajo vso pozornost usmeriti sami nase. } \\
\text { Delo jemljejo preprosto kot najeti delavci. }\end{array}$ & $\begin{array}{l}\text { Člani sprejemajo delo za svojo last in združijo svoje } \\
\text { moči, ker so zavezani istemu cilju, ki so ga sami } \\
\text { pomagali postaviti. }\end{array}$ \\
\hline $\begin{array}{l}\text { Članom prej naložijo, kaj morajo delati, kot da } \\
\text { bi jih spraševali, kakšen bi bil najboljši način. } \\
\text { Predlogov ne spodbujajo. }\end{array}$ & $\begin{array}{l}\text { Člani prispevajo k uspešnosti podjetja z izvirnostjo, } \\
\text { talentom in znanjem, to pa omogoči boljše } \\
\text { doseganje ciljev tima. }\end{array}$ \\
\hline $\begin{array}{l}\text { Člani ne zaupajo ciljem svojih sodelavcev, ker } \\
\text { ne razumejo njihove vloge v skupini. Izražanje } \\
\text { lastnega mnenja ali nestrinjanje se obravnava kot } \\
\text { nezaželeno, ker ne podpira, temveč deli enotnost } \\
\text { skupine. }\end{array}$ & $\begin{array}{l}\text { Člani delajo v ozračju zaupanja, drug drugega } \\
\text { spodbujajo, da prosto izrazijo svoje mnenje, } \\
\text { predloge, občutke ali nesoglasja. Vprašanja so } \\
\text { dobrodošla. }\end{array}$ \\
\hline $\begin{array}{l}\text { Člani so zelo previdni pri tem, kaj povedo, tako } \\
\text { da je resnično razumevanje v skupini nemogoče. } \\
\text { Lahko se pojavi namišljeno igranje vlog, postavijo } \\
\text { se pasti v komuniciranju, v katere se lahko ujamejo } \\
\text { vsi, ki niso dovolj previdni. }\end{array}$ & $\begin{array}{l}\text { Člani si prizadevajo za odprto in pošteno } \\
\text { komunikacijo. Trudijo se, da bi razumeli stališče } \\
\text { vsakega izmed njih. }\end{array}$ \\
\hline $\begin{array}{l}\text { Člani so za delo lahko dobro usposobljeni, vendar } \\
\text { jih vodja ali drugi sodelavci ovirajo, da bi znanje } \\
\text { lahko uporabili. }\end{array}$ & $\begin{array}{l}\text { Člane spodbujajo, da razvijajo svojo usposobljenost } \\
\text { in da to, kar so se naučili, uporabljajo tudi pri delu. } \\
\text { Tim jih pri tem povsem podpira. }\end{array}$ \\
\hline $\begin{array}{l}\text { Člani se znajdejo v konfliktnih situacijah, za katere } \\
\text { ne vedo, kako bi jih rešili. Njihov vodja lahko } \\
\text { odlaga posredovanje, dokler ni povzročena že } \\
\text { resna škoda. }\end{array}$ & $\begin{array}{l}\text { Člani priznavajo konflikt za normalen pojav v } \\
\text { medčloveških odnosih. } V \text { takšnih primerih vidijo } \\
\text { priložnost za nove rešitve in ustvarjalnost. Trudijo } \\
\text { se, da konflikt rešijo hitro in konstruktivno. }\end{array}$ \\
\hline $\begin{array}{l}\text { Člani lahko sodelujejo ali pa tudi ne pri odločitvah, } \\
\text { pomembnih za skupino. Skladnost z mnenjem } \\
\text { vodje je pogosto pomembnejša kot uspešni delovni } \\
\text { rezultati skupine. }\end{array}$ & $\begin{array}{l}\text { Člani sodelujejo pri odločitvah, pomembnih za } \\
\text { tim. Razumejo, da mora vodja sam sprejeti končno } \\
\text { odločitev ali ko je treba hitro ukrepati. Cilj je vedno } \\
\text { le uspešnost tima in nikoli skladnost z mnenjem } \\
\text { vodje. }\end{array}$ \\
\hline
\end{tabular}

\section{DEJAVNOSTI UVELJAVLJANJA TIMSKEGA DELA V SLOVENSKI VOJSKI}

Spremembe, ki so se pojavile v zadnjem desetletju prejšnjega stoletja, vplivajo na postopen razvoj družbe in vse večjo globalizacijo. To je pogoj, da morajo biti organizacije hitre, fleksibilne in nenehno sposobne izboljšati svoje delovanje, če hočejo biti uspešne, zato se je Ministrstvo za obrambo RS v srednjeročnih smernicah delovanja opredelilo, da bo spodbujalo iniciativnost, samokritičnost, inovativnost in timsko delo med pripadniki Slovenske vojske. 
Organiziranje v SV pomeni postavljanje razmerij in struktur (npr. tehnične, komunikacijske, motivacijske in oblastno-avtoritarne), v katerih bo SV kot organizacija delovala najbolj uspešno. Vse te strukture so povezane med seboj v eni skupini ali pa slojeviti organizacijski strukturi.

Ko govorimo o vojaškem sistemu, moramo povedati, da je z razvojem tehnike in tehnologije ter človeških odnosov postalo sodobno bojišče velik izziv za poveljnike. Ti morajo obvladati nove koncepte, ki vključujejo novo tehnologijo, in upoštevati kompleksnost človeške narave in vse bolj sofisticiranega načina bojevanja. Poznavanje konceptov vključuje tudi obvladovanje ljudi oziroma maksimalno izkoriščenost njihovih razpoložljivih potencialov, da $\mathrm{V}$ pravem trenutku in $\mathrm{Z}$ najmanjšimi človeškimi izgubami dobijo premoč nad nasprotnikom.

\section{ORGANIZACIJA VOJAŠKE ORGANIZACIJE IN ORGANIZIRANJE DELOVNIH PROCESOV V NJEJ}

Posebnost je v tem, da sta vodenje in ravnanje zaposlenih ali poklicnih vojakov bolj celovito in natančno urejena s predpisi. Hierarhija zaposlenih, ki se sicer pojavlja $\mathrm{v}$ vseh poklicih, ni nikjer tako zelo izrazita kot v vojski.

Pomen hierarhije v vojaški organizaciji je najbolj viden v zakonu s tega področja, v podzakonskih aktih in drugih pravilih. To je zajeto v Zakonu o obrambi, Pravilih službe v OS, Pravilu štabnega dela in drugih dokumentih, ki veljajo in opredeljujejo odgovornost za ukazovanje in izvajanje ukazov. Zlasti za častnike velja, da so hkrati nadrejeni in podrejeni, torej so $\mathrm{v}$ ambivalentni vlogi. Za izvedbo prejetega ukaza odgovarjajo nadrejenemu, hkrati pa jim ta ukaz dovoljuje, da sami ukažejo podrejenim.

Ker je treba ukaze nemudoma izpolniti, steče postopek ukazovanja po hierarhični lestvici zelo hitro. Če z vidika učinkovitega delovanja vojaške organizacije ni na razpolago časa za posebno razmišljanje o tem, ali ukaz izpolniti ali ne. Zato je v večini vojaških organizacij uveljavljeno pravilo, da se mora ukaz izvesti takoj ter upoštevati njegovo vsebinsko in časovno dimenzijo.

\section{POSEBNOST VOJAŠKE ORGANIZACIJE}

Vojaški sistem je posebna oblika, ki jo lahko primerjamo z ekonomskim sistemom, saj tudi zanj veljajo podobne ekonomske in organizacijske zakonitosti kakor za normalno gospodarstvo. Z ekonomskega kakor tudi z organizacijskega vidika mora ekonomizirati in se organizirati z omejenimi viri (finance, tehnologija ...) ter upoštevati ekonomsko in organizacijsko logiko poslovnih in organizacijskih procesov. 


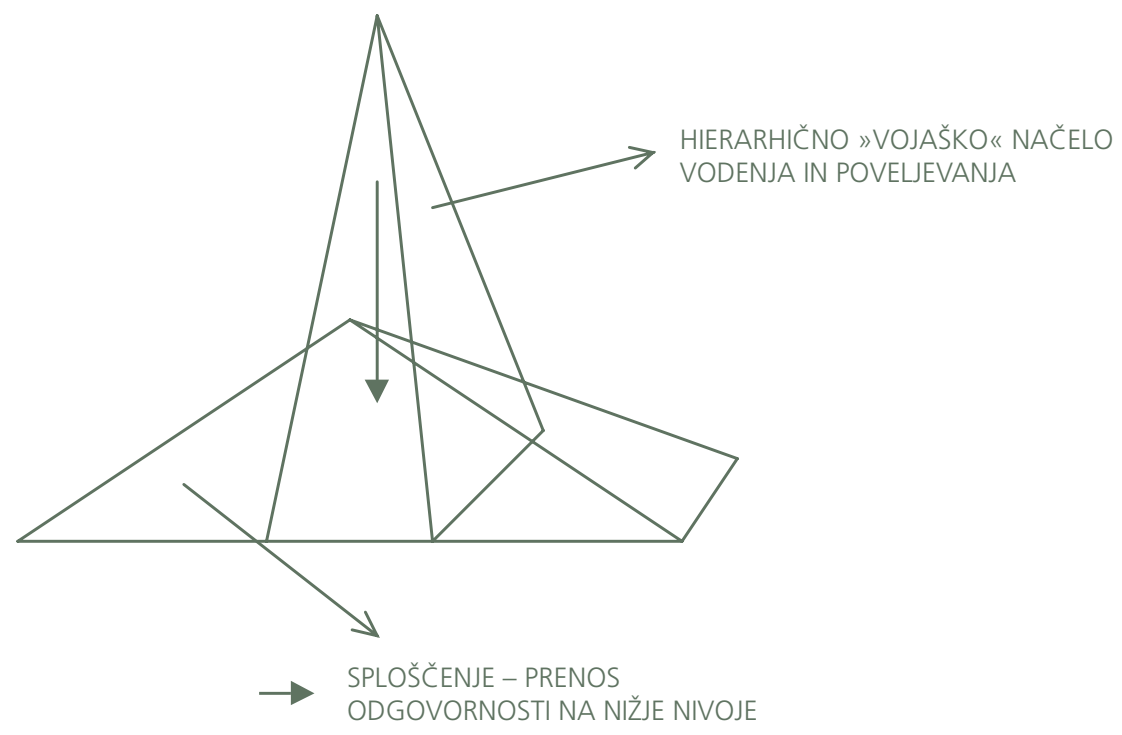

SODOBNO VOJSKOVANJE JE VOJSKOVANJE PAMETI IN RAZUMA, NE PA FIZIČNE IN OGNJENE MOČI!

Vojaški sistem je odvisen od ljudi kot elementov, ki ga sestavljajo, načina njihove organizacije (sistemska teorija), kulture njihovega vedenja, vojaškoorganizacijskih projektov, ki jih izpeljujejo, in rezultatov, ki so primerljivi in merljivi glede na zastavljene cilje in strategijo razvoja. Pri upravljanju vojaškega sistema-organizacije lahko uporabljamo podobne tehnike, kot jih obvladujejo menedžerji v podjetjih. Temeljna tehnika je podjetniški način organizacije in upravljanje vojske, ki temelji na pobudi posameznikov oziroma skupin, ki neprestano stremijo k izboljšanju vojaške doktrine, poveljevanja, organizacije in izvedbe vojaških nalog, ter na inovacijah na vseh področjih dela v vojski in podobno.

\section{PROCES VODENJA IN POVELJEVANJA V SV IN PODLAGA ZA ORGANIZIRANJE TIMSKEGA DELA}

Slovenska vojska se mora zgledovati po sistemih, ki so razvili učinkovito organiziranost in vodenje. Vodenje in poveljevanje morata zagotoviti glavni cilj delovanja SV. Dopustiti se mora več samoiniciativnosti v vodenju in poveljevanju - to posledično spremeni medosebne odnose v SV. Funkcijsko organiziranost mora vse bolj nadomeščati procesna organiziranost. Uspešnost SV je neposredno odvisna tudi od kulture okolja, saj njena naslonitev na vrednote okolja zagotavlja njeno uspešnost. Iz navedenega je razvidno, da morata vodenje in poveljevanja temeljiti na mnogih uspešnih menedžerskih prijemih. 
Poveljevanje je proces, v katerem poveljnik uveljavlja svoje pristojnosti ter vodi poveljstvo in podrejene enote v izvedbi sprejete naloge ali rešitvi problema. Proces poveljevanja obsega zmogljivosti, dejavnosti in postopke, ki jih poveljnik uporablja pri načrtovanju, organiziranju, vodenju in kontroli za izvedbo dejavnosti pri izvedbi neke naloge. Poveljevanje je pristojnost posameznika (poveljnika), pridobljena $\mathrm{z}$ zakonom, ko jo posameznik potrebuje za izvajanje funkcij uporabe enot in njihovega organiziranja ter kontrole pri izvajanju nalog. Namen poveljevanja je izpolniti naloge oziroma rešiti problem in s tem doseči zastavljen cilj. Objekti poveljevanja so poveljstva, enote in posamezniki.

Poveljevanje vključuje pristojnost in odgovornost za učinkovito izrabo razpoložljivih človeških virov za izvedbo sprejete naloge. Odgovornost za zdravje, moralo, disciplino in »blaginjo« podrejenih ter sprejem tveganja je sestavni del poveljevanja.

Poveljnik je odgovoren za vse, kar njegovo poveljstvo ali enota naredi oziroma česar ne naredi, in svoje odgovornosti ne more prenesti na drugega. Poveljnik je tisti, ki sprejme končno odločitev in je zanjo tudi odgovoren. Poveljnik delegira del svojih pooblastil glede vodenja poveljstva na druge ter spodbuja vzajemno zaupanje, tesnejše sodelovanje in timsko delo med vsemi člani poveljstva.

\section{PROJEKTNI TIM}

Za uspešno izvajanje nalog SV sta pomembna tudi izobraževanje in usposabljanje ljudi na vseh ravneh v SV. Dolgoročno oblikovanje pozitivnega pristopa zaposlenih pri izvajanju nalog je potrebno za izvajanje nalog doma in $\mathrm{v}$ tujini, $\mathrm{v}$ miru in izrednih razmerah. S tem bi povečali kakovost dela in zadovoljstvo pripadnikov SV. Preprečili bi izpad načrtovanih oblik usposabljanja in izobraževanja ter dosegli obvladovanje potrebnih vojaških obrambnih procesov, poleg tega pa tudi procesov za vzpostavljanje obrambne zagotovitve; s tem bi dosegli mednarodno povezljivost, zagotovili nacionalno varnost in kar je najpomembnejše - povečali bi bojno pripravljenost SV.

Predlagan je projekt, ki bi ga lahko uresničili na podlagi znanja in izkušenj zaposlenih na področju izobraževanja in usposabljanja v SV. Predstavljeni so idejni projekti oziroma zasnove - usmeritve za izvedbo projektov po predlaganem modelu.

Cilji projekta so:

1. spodbuditi v zaposlenih odnos »dobrega gospodarja«,

2. spodbuditi inovativnost in ustvarjalnost, dvigniti raven organizacijske kulture Slovenske vojske,

3. identifikacija zaposlenih s Slovensko vojsko,

4. zagotoviti pravočasno načrtovanje in pripravo kandidatov,

5. izboljšati stil vodenja in poveljevanja ter komunikacij,

6. ustvariti pogoje za normalen sistem poklicnega napredovanja. 
Projekt omogoča, da se s sistematičnim in ciljno programiranim izobraževanjem in usposabljanjem zaposlenih ustvarijo takšne ustvarjalne razmere za aktiviranje vseh intelektualnih potencialov, ki so v fazi nadaljnje gradnje SV in pomembnih odločitev.

Projekt ne omogoča hitrih učinkov in celotne nadomestitve zamujenih dejavnosti v preteklosti.

Nekatere pozitivne izkušnje iz preteklosti že imamo, saj sta izobraževanje in usposabljanje potekala usmerjeno in tudi z že določenimi ciljnimi skupinami. Te izkušnje lahko vgradimo v sistem nadaljnjega načrtnega izvajanja izobraževanja in usposabljanja zaposlenih.

Kadrovanje ima v Slovenski vojski pomembno t. i. funkcijo »prečnega prereza«. Posredno in neposredno vpliva na vsa področja dela. Kadrovanje v vseh oblikah izobraževanja je osredotočeno na vojaški menedžment najpomembnejših dejavnikov v obrambnih silah. Naša vizija je, da smo lahko le tako dobri, kot so dobri naši častniki, podčastniki in vojaki, zlasti stalne sestave. Torej mora biti vojaški menedžment sprejet in trdno zasidran v SV ter drugem delu MO kot izvajalcu sprejete politike izobraževanja. Po vsebini, odgovornosti in svoji vlogi umeščamo to vrsto menedžmenta k najpomembnejšim področjem vojaške obrambne politike.

Vojaškega menedžmenta ne oblikujejo le kadri in oddelki ali službe, ki so za to v Slovenski vojski in MO strokovno opredeljeni in pooblaščeni. Učinkovitost in uspeh »gospodarjenja« s kadri sta še zlasti odvisna od funkcionalnega sodelovanja vseh zaposlenih in tudi drugače vključenih, na vseh ravneh, v vojaški obrambni sistem. To velja predvsem za razvoj kadra, ki ima poseben pomen pri dolgoročnem zagotavljanju uspešnosti in učinkovitosti SV.

Izobraževanje in usposabljanje ter razvoj kadra potekajo v izredno dinamičnem okolju, zaradi najrazličnejših vplivov (spremembe varnostnih razmer, mednarodno povezovanje, nove tehnologije, omejitve zaposlovanja, različne izobrazbene in vojaškostrokovne osnove zaposlenih, fluktuacije idr.), zato morajo biti izobraževanje in usposabljanje ter razvoj kadra stalnica, ki sistemsko zagotavlja kvantitativno in kvalitativno potrebo po kakovostnih pripadnikih SV. Za izvajanje teh pomembnih elementov vojaškega obrambnega sistema pa morajo biti postavljeni ustrezni sistemi organizacije, vodenja in poveljevanja, koordinacije, načrtovanja in kontrole. Le s sistematičnim obvladovanjem vseh elementov oblikovanja celovitega sistema "gospodarjenja« s kadri lahko pričakujemo načrtovane in želene rezultate. V te dejavnosti morajo biti vključena vsa področja kadrovskega delovanja v SV in MO. V SV pričakujemo dolgoročen uspeh s potrebnim obvladovanjem procesov dela, v naši državi in z mednarodnem sodelovanjem, razvojem obrambnih sil, inovacijami, s posodabljanjem opreme in oborožitve ter predvsem s strokovnjaki na različnih področjih, ki bodo izobraženi in usposobljeni za izvajanje nalog v miru in izrednih razmerah ter vojni. 
Razvoj kadra v Slovenski vojski še ni uporabljen optimalno. Prizadeva pa se, da bi bili človeški viri uporabljeni glede na njihovo usposobljenost ter da bi se ti ljudje naučili timskega način razmišljanja in delovanja. Takšen način delovanja se mora uveljaviti na vseh ravneh SV. Seveda bosta za to potrebna stalno izobraževanje in intenzivno motiviranje za delo v timu. Operativni razvoj, načrtovanje usposabljanja kadra na ravni poveljstev, enot in zavodov ter tehnične postopke izvajajo strokovni sodelavci, seveda s koordinacijo strokovnih služb GŠSV ter SOK MORS. Vendar ti ne smejo pozabiti, da sta usposabljanje in delo v poveljstvih velika preizkušnja za timsko razmišljanje in timsko delo.

V CVŠ, v katerem so organizacijske enote in vodstva šol ter strokovni delavci in predavatelji ter vrsta poveljnikov enot, potekajo klasični procesi timskega dela. Če se tega ne upošteva, prihaja do zastojev v izobraževanju in usposabljanju. Organizacija v SV zahteva nemoteno izvajanje dela in za to sta potrebna določena stopnja izobraženosti in usposobljenosti pa tudi oblikovanje ciljnih skupin, ki bodo na podlagi timskega dela realizirale poti za kariero ter občutek za komunikacijo in identiteto v ožji in širši skupini.

\section{Primer projektnega tima}

1. Projektni svet: za izdelavo strategije izobraževanja in usposabljanja

2. Projektni tim: za izdelavo strategije izobraževanja in načrt za leto 2001: izvaja skupina strokovnjakov višjih častnikov od majorja do polkovnika

3. Strokovni sodelavci iz MO: se vključujejo po potrebi

4. Zunanji sodelavci: visoke šole, fakultete, izvajalci izobraževanja (po potrebi)

5. Drugi sodelavci: vključijo se po potrebi še z drugih področij, odločitev o tem sprejme po predlogu vodja projekta ali projektni svet

Člani projektne skupine (strokovni sodelavci in zunanji sodelavci) so vključeni samo občasno, ko so potrebne posamezne konzultacije ali opredelitve glede posameznih problemov pri izvajanju projekta. Celotno izvedbo projekta vodijo vodja projekta in član projektnega tima »ppk. NN«ter vodje podprojektov.

Nekatera področja se obdelajo z občasnim vključevanjem sodelavcev. Konzultacije in dodatne usmeritve so praviloma pridobljene od projektnega sveta.

Sklep Zaradi velikih izzivov iz okolja bo morala SV v prihodnosti upoštevati nove »prijeme« znotraj vodenja in poveljevanja ter same organizacije kakor tudi delovnih procesov v njej. Izzivi se bodo morali izražati v težnji, da je uveljavljanje timskega dela nujnost, saj je sodobno vojskovanje prepleteno in soodvisno zaradi mnogih znanj in veščin. Le na podlagi tega lahko poveljnik izbere najustreznejšo odločitev. V zvezi s tem čakajo skupine in posameznike vse večje zahteve po višji stopnji znanja in spretnosti, sposobnosti in iznajdljivosti. Zato bo tudi pomembno, da bo posameznik stalno motiviran za skupinsko/timsko opravljanje nalog. To delo ne bo več nekaj, kar bi bilo prepuščeno posamezniku. Zaradi vse večjih zahtev na delovnem mestu se bo moral stalno socializirati ter se permanentno izobraževati in usposabljati. Znova 
bi rad poudaril - in to se mi zdi zelo pomembno in koristno za SV, da je eden od pristopov za spoprijemanje s spremembami iz okolja - koncept učeče se organizacije. SV bi morala biti dovolj motivirana, da bi se izboljševale usposobljenosti njenih notranjih organizacij oziroma organizacijskih enot ob nenehnem osebnostnem razvoju in neprestanem učenju vseh njenih pripadnikov. Le pod tem pogojem bi se ohranjala učeča se organizacija, ki se imenuje - Slovenska vojska.

Visoka stopnja znanja in motiviranosti zaposlenih v SV bo omogočila, da se bodo zmanjšale blokade $\mathrm{v}$ ravneh $\mathrm{v}$ organizacijski hierarhiji in da se bo funkcijska organiziranost vse bolj nadomestila s procesno.

Moj prispevek o potrebi timskega dela v SV je nastal v obsegu, kakršen je bil potreben, če sem hotel zagovarjati potrebo po takšnem načinu dela. Ta prispevek je bil potreben tudi zato, ker se o tej problematiki še vedno premalo razpravlja, čeprav je mogoče čutiti potrebo po timskem načinu dela, torej po neki stalni povezljivosti ljudi in njihovi soodvisnosti. Ne smemo pozabiti, da mora to potekati v razmerah vojaške hierarhije, enostarešinstva in vojaške subordinacije. Praksa je pokazala, da sta se v enotah, poveljstvih in drugih organizacijskih strukturah, v katerih se je timsko delo začelo uporabljati bolj ali manj spontano, visoko dvignila motiviranost in občutek pripadnosti skupini/timu. Iz spontanih oblik se bo vsekakor prešlo na sistemsko, saj se v SV to vse bolj poudarja.

Za timsko delo so potrebni nekateri pogoji, ki morajo vključevati sistemska in ne spontana prizadevanja, še predvsem pri vodenju in poveljevanju. Le tako lahko dosežemo skupno vizijo - uspešen vojaški obrambni sistem, ki bo lahko opravil svoje naloge uspešno in učinkovito. Delovanje v timu bi bilo učinkovitejše in ravno to (učinkovitost in odličnost) zahteva naš kodeks, ki ni v nasprotju z zakonodajo na obrambnem področju. Vsekakor bi bilo umestno, da bi v podzakonskih predpisih potencirali to naravo dela, saj je edina alternativa pred stresi in frustracijami, ki jih doživlja posameznik, če je izoliran.

1. Ambrož, Milan, Učinkovita izraba virov v delovni skupini, Organizacija, letnik 32, št. 5, Kranj, maj 1999.

2. Bergant, Andrej, O analitiki dela, Organizacija, letnik 33, št. 9, Kranj, november 2000.

3. Boškovič, Desimir, Model formiranja organizacije za 21. stoletje, Organizacija, letnik 32, št. 5, Kranj, maj 1999.

4. Brejc, Miha, Ljudje in organizacija v javni upravi, VUŠ, Ljubljana 2000.

5. Kovač, Bogomir, Menedžerske metode in upravljanje Slovenske vojske, Dedalus, Ljubljana 1994.

6. Kralj, Janko, Pojmovanje znanosti o organizacijah, Organizacija, letnik 33, št. 7, Kranj, september 2000.

7. Kobentar, Jože, Izdelava strategije izobraževanja, GŠSV, Ljubljana 2001.

8. Lipičnik, Bogdan, Ravnanje z ljudmi pri delu, GV, 1998.

9. Mayer, Janez, Nastajanje celostnega pogleda - ključ za ustvarjalnost tima, Organizacija, letnik 34, št. 7, september 2001. 
10. Merc, Božidar, Vojstvo 1/96, Vojaška dolžnost in kazenska odgovornost, MORS, 1996.

11. Možina, Stane, Management, Didakta, 1994.

12. Mulej, Matjaž, in soavtorji, Dialektična in druge mehkosistemske teorije, Maribor 2000.

13. Nanut, Karlo, Učna gradiva CVŠ, Ljubljana 2000.

14. Pavlič, Tomaž, Oblikovanje tima, Poveljniško-štabna šola, Poljče 2001.

15. Tušek, Maks in Matej, Psihologija športa, Ljubljana 1994.

16. Tracy, Brian, Vrhunsko vodenje, prevod Saša Deleja in Maja Lihtenvalner, Vernar cosulting, Bled 2000.

17. Gradivo za seminar: Razvijanje timov II, SinesiS, d. o. o., Ljubljana 2001.

\section{Notranji viri}

1. Smernice za delo Ministrstva za obrambo do leta 2004, MORS, Ljubljana, februar 2001.

2. Poslovnik Generalštaba SV, GŠSV, Ljubljana, julij 2001.

3. Pravila štabnega dela, GŠSV, Ljubljana 2000. 